\title{
SHORT- AND MID-TERM EVOLUTION OF TOPSOIL ORGANIC MATTER AND BIOLOGICAL PROPERTIES AFTER PRESCRIBED BURNING FOR PASTURE RECOVERY (TELLA, CENTRAL PYRENEES, SPAIN)
}

Cecilia M. Armas-Herrera ${ }^{1 *}$, Clara Martí ${ }^{1,3}$, David Badía ${ }^{1,3}$, Oriol Ortiz-Perpiñáa ${ }^{1,3}$, Antonio Girona-García ${ }^{1,3}$, Juan Luis Mora ${ }^{2,3}$

1 Departamento de Ciencias Agrarias y del Medio Natural, Escuela Politécnica Superior de Huesca, Universidad de Zaragoza, Carretera de Cuarte s/n, 22071 Huesca, Spain

2 Departamento de Ciencias Agrarias y del Medio Natural, Facultad de Veterinaria, Universidad de Zaragoza, C/ Miguel Servet 177, 50013 Zaragoza, Spain

3 Instituto de Investigación en Ciencias Ambientales de Aragón (IUCA), Universidad de Zaragoza, Spain

*Correspondence to: C.M. Armas-Herrera, Departamento de Ciencias Agrarias y del Medio Natural, Escuela Politécnica Superior de Huesca, Universidad de Zaragoza, Carretera de Cuarte s/n, 22071 Huesca, Spain. E-mail: cmarmas@unizar.es. Telephone: +34 626371753

SHORT TITLE: EVOLUTION OF SOIL PROPERTIES AFTER PRESCRIBED BURNING IN THE PYRENEES

HIGHLIGHTS

Prescribed fire is used in the Pyrenees as a tool for managing grazing lands SOM and biological properties we examined at short- and mid-term after burning Fire effects remained at mid-term except microbial $C$ that returned to pre-fire values Warming due to cover loss and nutrients release have stimulated SOM mineralization

This article has been accepted for publication and undergone full peer review but has not been through the copyediting, typesetting, pagination and proofreading process which may lead to differences between this version and the Version of Record. Please cite this article as doi: 10.1002/ldr.2937

This article is protected by copyright. All rights reserved. 


\section{SHORT- AND MID-TERM EVOLUTION OF TOPSOIL ORGANIC MATTER AND BIOLOGICAL PROPERTIES AFTER PRESCRIBED BURNING FOR PASTURE RECOVERY (TELLA, CENTRAL PYRENEES, SPAIN)}

SHORT TITLE: EVOLUTION OF TOPSOIL PROPERTIES AFTER PRESCRIBED BURNING IN THE PYRENEES

\section{Abstract}

We determined the short and medium-term effects of prescribed burns on soil organic matter content and biological activity in grazing areas invaded by the shrub Echinospartum horridum (Vahl) Rothm. in the Pyrenees of Huesca (Spain). Soil samples were collected at 0-1, 1-2 and 2-3 cm depths in triplicate just before the burn, immediately after the burn (T0), and one and five years later (T1, T5). We analysed the contents of total soil organic $\mathrm{C}(\mathrm{SOC})$ and $\mathrm{N}$, soil respiration, microbial biomass $\mathrm{C}$, and $\beta$ D-glucosidase and acid phosphatase activities. Fire provoked an immediate high decrease in the contents of SOC $(-40.2 \%)$ and $\mathrm{N}(-26.3 \%)$ in the first $3 \mathrm{~cm}$, which were even lower at T5 $(-50.3 \%$ and $-46.5 \%$, respectively). This can be explained as follows: (i) low incorporation of burned organic matter due to removal by wind and runoff; (ii) changes in microclimate increasing soil temperature and enhancing mineralization; and (iii) a stimulating effect on decomposition due to the release of nutrients. Soil biological activity was affected at T0 in the first $3 \mathrm{~cm}(-49.3 \%$ glucosidase, $-48.2 \%$ phosphatase and $-54.5 \%$ respiration rate). Microbial biomass $C$ content was also affected by fire at T0 $(-32.3 \%)$ but was close to its initial value at T5. The results suggest that these soils are particularly sensitive to fire. Adjusting the frequency and intensity of the burns is necessary to minimize their impact on the soil and to ensure the suitability of this management practice.

Key words: shrub encroachment, pastureland, prescribed burning, soil organic matter, soil biological activity

\section{INTRODUCTION}

Grazing lands are important to the global carbon (C) cycle because they store between 20 and $35 \%$ of the world's soil organic matter (SOM) (Janzen, 2005) and account for about $25 \%$ of the global potential for soil C sequestration (Follett \& Reed, 2010). Grazing lands in Europe are currently largely restricted to mountain areas, but they contain ecosystems that have the richest biodiversity of the continent (Tälle et al., 2016). C storage in the soils of the mountain areas is one of the largest on a global scale (Jobbágy \& Jackson, 2000). This is due to low temperatures, which slow down the decomposition and 
loss of organic matter (Körner 2003). Because of this, mountain soils contain a large proportion of labile SOM, which makes them more sensitive to climate changes (Budge et al., 2011).

Most of the grazing land in European mountain areas depends on its maintenance by regular disturbance by grazing and/or fire, which prevents succession to woody vegetation. However, the cessation of fire use due to wildfire risk and a decrease in livestock pressure over the past several decades have allowed encroachment of shrubs into the grazing lands throughout the European mountain ranges (Cernusca et al., 1996; Galvánek \& Lepš, 2008). Shrub encroachment can have significant impacts on ecosystems, including alterations of the dynamics of water and nutrients in soil, increased fire and avalanche hazards, and a loss of biodiversity and pasture resources (Montané et al., 2010). In the Pyrenees, woody species have increased their biomass by $47 \%$ between 1975 and 2005 (Komac et al., 2013). One of the most important encroaching species in this area is the thorny cushion dwarf Echinospartum horridum (Vahl) Rothm. E. horridum grows naturally in rocky habitats, but spreads rapidly onto undergrazed pastures, where it behaves as an invasive species, forming dense, almost monospecific stands (Komac et al., 2011b).

In recent years, prescribed burning has gained renewed attention as a substitutive source of disturbance and, thus, as a tool for fighting shrub encroachment (Fernandes et al. 2013). However, it has some drawbacks, such as increased erosion rates during the months following fire, the loss of nutrients (Gómez-Rey et al., 2013) and the enhanced spread of pyrophytic species (Girard et al., 2008). Prescribed fire is less expensive than the mechanical removal of shrubs (Goldammer \& Montiel, 2010) and may be the only realistic way to stop shrub encroachment in certain mountain areas (Lyet et al., 2009), coupled with moderate grazing (Komac et al., 2011a). However, few studies exist on the environmental effects of prescribed burning of shrubland in subalpine environments (San Emeterio et al., 2016; Girona-García et al., 2017).

The response of soils to fire is complex and depends on fire severity, as well as on soil and vegetation characteristics (Certini, 2005). Fire impacts on soils include the loss of SOM and nutrients by combustion and increased post-fire runoff and erosion rates, which are related to decreased aggregate stability (Badía-Villas et al., 2014; Mataix-Solera et al., 2011). On the other hand, fire causes some organic matter to become "pyromorphic" humus, which includes refractory and oxidation resistant organic molecules (Knicker et al., 2005). Fire also affects soil microbiota, which is responsible for the cycling of SOM, and fungi are much more sensitive than bacteria (Boerner et al., 2000), which is reflected in the changes of the composition of the microbial community (Barreiro et al. 2016). Soil enzyme activities are also affected by both the denaturation and deactivation of enzymes at high 
temperatures (Knicker, 2007) and by changes in the availability of microbial substrates as a result of fire (Boerner et al. 2000).

The objective of this study was to investigate the short to medium-term impacts of prescribed burns on the soils of grazed land in mountain areas to improve this management tool in terms of the frequency and intensity of the burns. To this aim, we analysed soils one year and five years following a controlled burn of $E$. horridum scrub in the Central Pyrenees (Huesca, Spain). The immediate effects of this experimental burning on the SOM and soil biological properties were reported in a previous work (Armas-Herrera et al., 2016). In that work, larger-than-expected immediate effects of the prescribed burning on these properties were found, which were more in line with the typical effects of summer wildfires than with the low impacts generally attributed to prescribed fire. Examining the changes in the short and mid-term were beyond the scope of that study. Based on previous results, our preliminary hypotheses were that (a) the soils would start to recover at the short term (one year or less) and (b) that a complete recovery would occur in the medium term (five years or less). The following specific objectives were pursued: (a) to determine the depth and degree to which the soils remained affected over the first years following a burn in terms of SOM content and soil biological properties, and (b) to study the resistance and resilience of the soil microbial biomass and activity to fire disturbance, as inferred from soil respiration and enzyme activity values.

\section{MATERIAL AND METHODS}

\section{Study area and field work}

The study site is located in an extensive grazing area in the municipal district of Tella-Sin (Huesca) at 1875 m.a.s.l. The average annual precipitation is $1700 \mathrm{~mm}$ and the average annual temperature is 5 ${ }^{\circ} \mathrm{C}$. The soils, classified as Leptic Eutric Cambisols (Loamic, Humic), are shallow and irregular in depth, with limestone outcrops alternating with soils thick enough to support high quality pastures of Bromion erecti Koch 1926 and Nardion strictae Braun-Blanquet 1926, which are grazed by sheep, goat, horse, and cattle herds. The livestock population is barely one third of what was supported 50 years ago. As a result, a large area is now occupied by dense shrub thickets of $E$. horridum with canopy cover close to $100 \%$ (Figure 1A).

Prescribed burning of E. horridum shrublands is performed in the Central Pyrenees by the Forest Fire Prevention Team (EPRIF) at the request of local sheperds, with the aimed of promoting the growth of grass species that can be grazed by the livestock. In April 2015, a prescribed burn was performed in a 12.5 ha plot with slopes ranging from 10 to $40 \%$. Temperatures during the fire were measured with thermocouples located in the mineral soil at $1 \mathrm{~cm}$ and $2 \mathrm{~cm}$ depths. The burn was initiated from the top and from the foot of the slope at the same time, with both flame fronts eventually merging in the 
middle area, resulting in very high fire intensity (Figure 1B). The highest temperatures measured were $397^{\circ} \mathrm{C}$ at a $1 \mathrm{~cm}$ depth and $121^{\circ} \mathrm{C}$ at a $2 \mathrm{~cm}$ depth. Further information on the experimental burn, the study area, and the soil properties can be found in Armas-Herrera et al. (2016). Near the plot burned in 2015 (approximately $100 \mathrm{~m}$ ), a plot with similar area (12.6 ha) was burned in February 2011. The two plots had a similar slope aspect, gradient and length, elevation, parent material and soil morphology. We do not have data on the temperatures reached in the 2011 burn, but EPRIF team reported to us that both burns were very similar in terms of intensity and severity.

The immediate and short-term effects of the 2015 burn were studied at three sampling points located equidistant along an NE-SW transect from the top to the bottom part of the burned plot. In each point, samples were taken from the top soil layer at three depth intervals $(0-1,1-2$ and $2-3 \mathrm{~cm})$. We focused on the very top layer of soil on the basis of our previous work (Badía et al., 2014; Aznar et al., 2016) which shows that high temperatures during fire often only reach the first one or two $\mathrm{cm}$ of soil depth. The samples were collected immediately before (unburned control) and a few hours after the burn (burned T0) in April 2015 and one year after the burn in April 2016 (burned T1). In addition, a similar transect was conducted in the burned plot in 2011, and soil samples were collected in April 2016, five years after the burn (burned T5). All samplings were carried out at the end of the winter (with the precise date depending on the weather of the year) to avoid confounding with seasonal trends.

Plant cover was calculated at T1 and T5 by interpreting orthophotographs of the soil surface taken at $1.7 \mathrm{~m}$ height, with an Olympus digital camera (OM-D EM-10). Photographs of the soil surface covered an area of $3.26 \mathrm{~m}^{2}(2.08 \times 1.57)$. For each image, we calculated the proportion of bare soil, stones or rocks, burned plant material, herbaceous vegetation and organic debris (Table 1). One year after burning (T1), the plot burned in 2015 was abundantly recolonized by E. horridum saplings, with few thorns and at a 1-6 cm height, as well as by bulb and rhizome sprouts from Carex flacca Schreb., $C$. humilis Leyss., Euphorbia cyparissias L., Iris latifolia (Mill.) Voss, Teucrium chamaedrys L. and Carduus carlinifolius Lam (average plant cover of $14 \%$ ) (Figure 1C). In turn, the plot burned in 2011 (T5) had $43 \%$ cover of very thorny E. horridum at approximately 10-15 cm in height in 2016 (Figure 1D).

\section{Laboratory analysis}

All soil samples were sieved at $2 \mathrm{~mm}$ and kept at $4{ }^{\circ} \mathrm{C}$ until analysis. The water content was determined at $105^{\circ} \mathrm{C}$, and the results of all analyses were calculated on a dry weight basis. Total soil organic $\mathrm{C}$ $(\mathrm{SOC})$ and nitrogen $(\mathrm{N})$ were measured on a Vario Max CN macro elemental analyser (Elementar Analysensysteme $\mathrm{GmbH}$, Hanau). Microbial biomass $\mathrm{C}$ was obtained by the chloroform fumigationextraction method (Vance et al., 1987). Potential soil C mineralization rates were determined in a 28 
day-incubation of soil samples at optimum moisture (50\% field capacity) and temperature $\left(25^{\circ} \mathrm{C}\right)$. The emitted $\mathrm{CO}_{2}$ was captured with alkali traps (Anderson, 1982) and was determined on days 1, 2, 4, $7,10,14,18,22$, and 28 following the beginning of the incubation. The accumulated $\mathrm{C}-\mathrm{CO}_{2}$ values were expressed per dry weight and time ( $C-\mathrm{CO}_{2}$ efflux). $\beta$-D-glucosidase and acid phosphatase enzyme activities were analysed according to the methods of Eivazi \& Tabatabai (1988) and Saá et al. (1993), respectively.

\section{Data analysis}

Soil properties were analysed using a repeated measures ANOVA with the time elapsed since the burn (Time) as the fixed factor and soil depth (Depth) as the repeated measure. Although the samples were obtained from two different plots (unburned control, burned T0, and burned T1 from the burned plot in 2015 and burned T5 from the burned plot in 2011), they were considered representations of the different stages in a single post-fire sequence and were all included in the analysis. The variables were checked for normality and sphericity, and when necessary, they were inverse-, log- or roottransformed before ANOVA. Differences between single groups within a statically significant factor were assessed using Fisher's Least Significant Difference (LSD) test. A significance level of $P<0.05$ was used for all tests. All analyses were carried out using SPSS for Windows (version 20, SPSS Inc., Chicago, IL, USA).

Although the recovery of soil properties to their pre-fire levels is not necessarily desirable, their maintenance and reversion over time are meaningful for assessing the sustainability of burning and the suitable burning frequency. Thus, we assessed the fire resistance, recovery and resilience of SOC, $\mathrm{N}$, microbial biomass $\mathrm{C}$, soil respiration rates and acid phosphatase and $\beta$-D-glucosidase activities with the following formulas, given by López-Poma \& Bautista (2014):

Resistance (RS): -100 [(UB-B $\left.\left.\mathrm{B}_{0}\right) / \mathrm{UB}\right]$

Recovery (RC): -100 [(UB-Bx)/UB]

Resilience (RL): - $(\mathrm{RS}-\mathrm{RC})$ at $\mathrm{t}=1$ year and $\mathrm{t}=5$ years

where UB is the value of the variable in the unburned control soil, $B_{0}$ represents the value at $T 0$, and $B_{x}$ corresponds to the value at $\mathrm{T} 1$ or T5. RS and RC values of zero indicate maximum resistance and full recovery at a given time after fire, respectively, whereas negative values are indicators of lower RS and RC. RS can be positive when the value of the target variable in burned soils is higher than in unburned soils. A value of zero RL means no resilience, a positive value indicates resilience and a negative value represents a further decrease in the values of the response variable compared to the initial impact of fire. 


\section{RESULTS}

The contents of total SOC and $\mathrm{N}$ decreased with depth, being significantly different at $0-1 \mathrm{~cm}, 1-2 \mathrm{~cm}$ and $2-3 \mathrm{~cm}$, and the prescribed burn led to a significant decrease of their contents (Tables 2,3, Figures 2A, 2B). The interaction Time $x$ Depth was not significant, i.e., no differences were found in the changes associated with time after the burn between the three soil depths. The amount of SOC and $\mathrm{N}$ tended to decrease with time after the burn. Thus, one year later (T1), SOC and N contents were slightly (not significantly) lower compared to the values just after the burn (TO) and were even lower in the soils burned five years earlier (T5), where the $\mathrm{N}$ content was significantly lower compared to the soils just after fire (T0). These results indicate a low resilience for both parameters, being lower for $\mathrm{N}$. The different behaviour of both elements is reflected in the $\mathrm{C} / \mathrm{N}$ ratio (Figure $2 \mathrm{C}$ ), which decreased in the short term (T0 and T1) due to the prescribed burn, but at T5 it was higher although still significantly different to those of soils analysed before burning.

The amount of microbial biomass $C$ did not show significant variations with depth, but it was significantly affected by fire (Figure 2D). The interaction Time $x$ Depth was not significant, but a lower immediate impact of the burn was observed at a greater soil depth, as reflected in the resistance indexes (Tables 2,3). The burn effect was similar at T0 and T1. The microbial C contents at T5 did not show significant differences with respect to the control soils, thus revealed the highest values of resilience among all variables studied.

The activities of enzymes $\beta$-D-glucosidase and acid phosphatase showed smaller or no significant differences with soil depth, whereas they decreased significantly just after the burn (TO) (Tables 2,3, Figure 3A, 3B). The enzyme activities continued to decline at the short term (T1), although more slowly with soil depth for the $\beta$-D-glucosidase, as mirrored by the significant interaction between Time and Depth. Both enzymes showed higher activities at T5, but were still much lower than before burning. The resilience of enzymatic activity was low for both enzymes, especially in the case of phosphatase, and resilience was somewhat higher for $\beta$-D-glucosidase.

The $\mathrm{C}-\mathrm{CO}_{2}$ efflux was highest in the uppermost $\mathrm{cm}$ of soil $(0-1 \mathrm{~cm})$ and was lowest at the $2-3 \mathrm{~cm}$ depth. It decreased significantly at TO (Tables $\mathbf{2 , 3}$, Figure $\mathbf{3 C}$ ), but there was no significant interaction of Time $x$ Depth, indicating that this decrease was similar for the upper $3 \mathrm{~cm}$ of soil. The $\mathrm{C}-\mathrm{CO}_{2}$ efflux decreased further at $T 1$ and showed comparatively higher values at T5, although they were lower than that observed in the soils analysed before the burn.

This article is protected by copyright. All rights reserved. 


\section{DISCUSSION}

\section{Impacts of prescribed burning on soil organic matter}

The decrease of SOM within the first $3 \mathrm{~cm}$ contrasts with the results found in other studies with similar time scales in areas subjected to prescribed fires. Most studies on this topic only describe small decreases (not significant) as a result of the lower intensity and severity fires (Alexis et al., 2012; San Emeterio et al., 2016) or increases due to the inputs of ashes and charred residues derived from burning (Alcañiz et al., 2016; Larroulet et al., 2016; Rutigliano et al., 2007). In these studies, the initial SOM values generally recovered in the short or medium term. More in line with our results, BadíaVillas et al. (2014) and Aznar et al. (2016) reported, under laboratory controlled conditions, significant C losses ranging from $-50 \%$ to $-75 \%$ in the first $2 \mathrm{~cm}$ soil depth, where temperature reached about $300^{\circ} \mathrm{C}$ at $1 \mathrm{~cm}$ soil depth, and Girona-García et al. (2017) recently reported C losses of $-52 \%$ after burning of a $E$. horridum stand in a nearby area in the Pyrenees. The $\mathrm{C} / \mathrm{N}$ ratio decrease found in the short term after the burn is well known in the literature for soils after a fire, and can result from the release of C from certain thermally-unstable plant constituents (e.g. cellulose), as well as from the preferential immobilization of $\mathrm{N}$ over $\mathrm{C}$ into pyrogenic heteroaromatic compounds during charring (Knicker, 2007; Knicker, 2011). The mid-term trend to return to a $\mathrm{C} / \mathrm{N}$ value close to that of the soil prior to the burn indicates a certain degree of recovery of the quality of SOM, which contrasts with the significant loss of the total SOM content.

In view of our results, it seems evident that the ashes derived from the burn were hardly incorporated into the soil. This suggests a loss of the ash material, which can be rapidly removed from the soil surface by wind and post-fire rain (Bodí et al., 2014). SOM losses persisted for some time after fire, likely due to high decomposition rates, enhanced by the release of nutrients by fire, and accelerated by the soil warming resulting from the loss of vegetation cover and partially the litter.

\section{Temporal evolution of soil biological activity}

In general, the results obtained in this work are consistent with data reported in the literature regarding the fire effects on the composition, biomass and activity of microbial communities suggesting that they depend mainly on the severity of the fire (Knicker 2007). Our results in the short and mid-term (T1 and T5) coincide with those of Fontúrbel et al. (2016), who observed a decrease in $\beta$-D-glucosidase and acid phosphatase activities $(0-2 \mathrm{~cm})$ one year after a prescribed scrub burn at low intensity ( $58^{\circ} \mathrm{C}$ at the soil surface), which remained unrecovered four years later; however, contrary to our results, the soil microbial C totally recovered one year later. Barreiro et al. (2010) found an initial decrease of $\beta$-D-glucosidase activity ranging from -73 to $-86 \%$ in the first $2 \mathrm{~cm}$ of soil after a prescribed burning. Similar to our results, these values were even lower one year after the burn than 
immediately after the burn, although five years later, $\beta$-D-glucosidase activity had been fully recovered, which contrasts with our results. Choromanska \& DeLuca (2001) found that soil microbial C was not recovered until two years after a prescribed burning $(0-10 \mathrm{~cm})$; and Fritze et al. (1993) detected similar values in soil microbial $\mathrm{C}$ between 5 and 9 years after burning. The apparent recovery of microbial biomass $\mathrm{C}$ detected at T5 does not necessarily imply the recovery of the original microbial community structure prior to the burn, since it may have been affected by changes in soil conditions, e.g. in the availability of substrates for microorganisms (Fontúrbel et al., 2012). On the other hand, our findings coincide with those generally reported regarding the greater sensitivity of phosphatase than $\beta$-D-glucosidase to fire. López-Poma \& Bautista (2014) observed that $\beta$-D-glucosidase and phosphatase activities were similarly affected by a controlled burn $\left(492 \pm 32{ }^{\circ} \mathrm{C}\right.$, on the soil surface). However, whereas $\beta$-D-glucosidase recovered fully after 3 years in the first $5 \mathrm{~cm}$ of the soil, acid phosphatase did not recover during the same period. Some authors have suggested that fire intensity is related to an intense mineralizing effect of organic $P$ and that the release of inorganic $P$ could reduce the activity of acid phosphatase (Saá et al., 1993, 1998).

On the other hand, the low respiration rates detected in burned soils (T0, $\mathrm{T} 1$, and $\mathrm{T5}$ ) compared to unburned soils can be attributed to the high intensity and severity of the burn, which were higher than expected for a prescribed burning (Armas-Herrera et al., 2016). Many studies on this subject observed decreases in the soil respiration rates in the short term after a prescribed burning (Choromanska \& DeLuca, 2001; Fritze et al., 1993; Pietikaeinen \& Fritze, 1995), which is consistent with our results. However, in none of these studies, the decrease was associated with a decrease in SOC; moreover, increases of SOC were detected. Bonamomi et al. (2017) provided evidence that, in burned soils, the greater the fire impact, the lower the respiration rates, which may be due to a greater accumulation of recalcitrant $\mathrm{C}$ and a greater loss of labile $\mathrm{C}$.

\section{Implications for the management of the pastoral ecosystem}

The results of this work provide valuable conclusions regarding the sustainability of prescribed burns in mountain ecosystems. On the one hand, it is particularly important to control fire intensity so that temperatures in the top soil centimetres do not exceed the threshold of the temperature at which SOM consumption becomes significant $\left(\approx 200-250^{\circ} \mathrm{C}\right.$ ) (Certini, 2005). In low intensity burns, the impacts on soil are low, and recovery is fast. Thus, the impacts are often considered neutral or even positive due to an enrichment in bioavailable nutrients, the protection from erosion by partially burned litter remaining after fire, and even an enrichment in SOM by the incorporation of partially burnt material (Knicker 2007; Fernandes et al. 2013).

This article is protected by copyright. All rights reserved. 
On the other hand, it is of great importance to adjust the burn frequency to guarantee the sustainability of this practice (Williams et al., 2012). Burning at a frequency lower than the recovery time will not have long-term impact on soils, whereas burning at a shorter frequency will eventually result in cumulative effects, until a new stable state is reached. In any case, low recovery rates limit the optimum frequency of burning. According to our results, the recovery of soil conditions to that prior to a burn appears to be still far at current time, five years after the prescribed burn.

Much likely, prescribed burning at a sustainable frequency will not be able to prevent the $E$. horridum shrub from dominating the area. Furthermore, the invasive $E$. horridum has a great capacity for regrowth after a fire, which results from massive germination of its seeds and allows this plant to regenerate quickly and recolonize the burned areas (Marinas et al. 2004). For this reason, it is not possible to rely solely on regular burns, and it is essential to maintain a sufficient livestock density that limits the regeneration of the shrubland (Fuhlendorf et al., 2009).

Future research should examine the long-term consequences of prescribed burns in the soils of the Central Pyrenees, especially in regards to its effects on SOM cycling and soil biological activity, soil loss by erosion, the interaction of prescribed burns and livestock density, and the monitoring of the evolution of vegetation cover. This knowledge will help in adopting sustainable management practices that consider both the suitable frequency of application of prescribed burns that allows the functional recovery of the soil, and the type and degree of grazing that reduces shrub encroachment in mountain pastures, guaranteeing the conservation of these ecosystems.

\section{CONCLUSIONS}

All soil properties studied were modified by fire, with variations in the extent of the effects, the soil depths affected, and the recovery and resilience in the short (one year) and medium term (five years). Fire seems to have a significant impact on the dynamics and turnover of organic matter in the first 3 $\mathrm{cm}$ of the soil, which remained even after five years. The magnitude of this impact is consistent with the high temperatures recorded in soil during the prescribed burn. The loss of vegetation cover and partially the litter probably increased the soil temperature, thereby stimulating the mineralization of SOM at short and mid-term, while the release of nutrients sequestered in the SOM as a result of the fire could also stimulate its decomposition. Only the content of microbial $\mathrm{C}$ seems to have recovered in the medium term to its initial values prior to the burn. Our results contrasted with those obtained in most studies carried out on soils after prescribed burning, where the effects on soil were of a smaller magnitude, and the recovery to values prior to the burn was relatively fast.

Given this information, it is necessary to continue the study of the evolution of SOM content and soil biological activity in the mid- and long term, as well as to complement it with measures of the 
magnitude of soil loss, while monitoring the evolution of vegetation cover and the consumption of $E$. horridum by livestock; this will allow an assessment of the appropriateness of this practice and an adjustment to the frequency and intensity of burns to minimize their impacts on the soil.

\section{ACKNOWLEDGEMENTS}

We are grateful to Rafael de Partearroyo and Raúl Vicente (EPRIF, Huesca) for allowing us to participate in the prescribed burning program, and to Janielle S. Pereira and Daniel Gómez García for their help during the field work. This study was supported by the Spanish Government Project CGL2013-43440-R and a grant from the Instituto de Estudios Altoaragoneses (Provincial Council of Huesca). It is a contribution by the PaleoQ group (Aragón Regional Government).

\section{REFERENCES}

Alcañiz M, Outeiro L, Francos M, Farguell J, Úbeda X. 2016. Long-term dynamics of soil chemical properties after a prescribed fire in a Mediterranean forest (Montgrí Massif, Catalonia, Spain). Science of the total environment 572: 1329-1335. DOI: 10.1016/j.scitotenv.2016.01.115.

Alexis MA, Rasse DP, Knicker H, Anquetil C, Rumpel C. 2012. Evolution of soil organic matter after prescribed fire: A 20-year chronosequence. Geoderma 189-190: 98-107. DOI: 10.1016/j.geoderma.2012.05.003.

Anderson JPE. 1982. Soil respiration. In Methods of Soil Analysis Part 2 Chemical and Microbiological Properties, Page AL (ed), American Society of Agronomy Inc., Soil Science Society of America Inc., Madison, Wisconsin, 831-871.

Armas-Herrera CM, Martí C, Badía D, Ortiz-Perpiñá O, Girona-García A, Porta J. 2016. Immediate effects of prescribed burning in the Central Pyrenees on the amount and stability of topsoil organic matter. Catena 147: 238-244. DOI: 10.1016/j.catena.2016.07.016.

Aznar JM, González-Pérez JA, Badía D, Martí C. 2016. At what depth are the properties of a gypseous forest topsoil affected by burning? Land Degradation and Development 27: 1344-1353. DOI: 10.1002/ldr.2258.

Badía-Villas D, González-Pérez JA, Aznar JM, Arjona-Gracia B, Martí-Dalmau C. 2014. Changes in water repellency, aggregation and organic matter of a mollic horizon burned in 
laboratory: Soil depth affected by fire. Geoderma 213: 400-407. DOI: 10.1016/j.geoderma.2013.08.038.

Barreiro A, Martín A, Carballas T, Díaz-Raviña M. 2016. Long-term response of soil microbial communities to fire and fire-fighting chemicals. Biology and Fertility of Soils. DOI $10.1007 / \mathrm{s} 00374-016-1133-5$

Barreiro A, Martín A, Carballas T, Díaz-Raviña M. 2010. Response of soil microbial communities to fire and fire-fighting chemicals. Science of the Total Environment 408: 6172-6178. DOI: 10.1016/j.scitotenv.2010.09.011.

Bodí MB, Martin DA, Balfour VN, Santín C, Doerr SH, Pereira P, Cerdà A, Mataix-Solera J. 2014. Wildland fire ash: Production, composition and eco-hydro-geomorphic effects. EarthScience Reviews 130: 103-127. DOI: 10.1016/j.earscirev.2013.12.007.

Boerner REJ, Decker KLM, Sutherland EK. 2000. Prescribed burning effects on soil enzyme activity in a southern Ohio hardwood forest: A landscape-scale analysis. Soil Biology and Biochemistry 32: 899-908. DOI: 10.1016/S0038-0717(99)00208-4.

Bonanomi G, Incerti G, Abd El-Gawad AM, Cesarano G, Sarker TC, Saulino L, Lanzotti V, Saracino A, Rego FC, Mazzoleni S. 2017. Comparing chemistry and bioactivity of burned versus decomposed plant litter: different pathways but same result?. Ecology. DOI: 10.1002/ecy.2053.

Budge K, Leifeld J, Hiltbrunner E, Fuhrer J. 2011. Alpine grassland soils contain large proportion of labile carbon but indicate long turnover times. Biogeosciences 8: 19111923. DOI: 10.5194/bg-8-1911-2011.

Cernusca A, Tappeiner U, Bahn M, Bayfield N, Chemini C, Fillat F, Graber W, Rosset M, Siegwolf R, Tenhunen J. 1996. Ecomont - Ecological effects of land use changes on European terrestrial mountain ecosystems. Pirineos 147-148: 145-172. DOI: 10.3989/pirineos.1996.v147-148.141.

Certini G. 2005. Effects of fire on properties of forest soils: A review. Oecologia 143: 1-10. DOI: $10.1007 / \mathrm{s} 00442-004-1788-8$.

Choromanska U, DeLuca TH. 2001. Prescribed fire alters the impact of wildfire on soil biochemical properties in a ponderosa pine forest. Soil Science Society of America Journal 65: 232-238. DOI: 10.2136/sssaj2001.651232x. 
Eivazi F, Tabatabai MA. 1988. Glucosidases and galactosidases in soils. Soil Biology and Biochemistry 20: 601-606. DOI: 10.1016/0038-0717(88)90141-1.

Fernandes PM, Davies GM, Ascoli D, Fernández C, Moreira F, Rigolot E, Stoof CR, Vega JA, Molina D. 2013. Prescribed burning in southern Europe: Developing fire management in a dynamic landscape. Frontiers in Ecology and the Environment 11: 4-14. DOI: $10.1890 / 120298$.

Follett RF, Reed DA. 2010. Soil carbon sequestration in grazing lands: societal benefits and policy implications. Rangeland Ecology \& Management 63: 4-15. DOI: 10.2111/08225.1.

Fontúrbel MT, Barreiro A, Vega JA, Martín A, Jiménez E, Carballas T, Fernández C, Díaz-Raviña M. 2012. Effects of an experimental fire and post-fire stabilization treatments on soil microbial communities. Geoderma 191: 51-60. DOI: 10.1016/j.geoderma.2012.01.037.

Fontúrbel MT, Fernández C, Vega JA. 2016. Prescribed burning versus mechanical treatments as shrubland management options in NW Spain: Mid-term soil microbial response. Applied Soil Ecology 107: 334-346. DOI: 10.1016/j.apsoil.2016.07.008.

Fritze H, Pennanen T, Pietikäinen J. 1993. Recovery of soil microbial biomass and activity from prescribed burning. Canadian Journal of Forest Research 23: 1286-1290. DOI: 10.1139/x93-164.

Fuhlendorf SD, Engle DM, Kerby J, Hamilton R. 2009. Pyric herbivory: Rewilding landscapes through the recoupling of fire and grazing. Conservation Biology 23: 588-598. DOI: 10.1111/j.1523-1739.2008.01139.x.

Galvánek D, Lepš J. 2008. Changes of species richness pattern in mountain grasslands: Abandonment versus restoration. Biodiversity and Conservation 17: 3241-3253. DOI: 10.1007/s10531-008-9424-2.

Girard N, Duru M, Hazard L, Magda D. 2008. Categorising farming practices to design sustainable land-use management in mountain areas. Agronomy for Sustainable Development 28: 333-343. DOI: 10.1051/agro:2007046.

Girona-García A, Badía-Villas D, Martí-Dalmau C, Ortiz-Perpiñá O, Mora JL, Armas-Herrera CM. 2017. Effects of prescribed fire for pasture management on soil organic matter and biological properties: A 1-year study case in the Central Pyrenees. Science of The Total 
Environment. DOI: 10.1016/j.scitotenv.2017.09.127

Goldammer JG, Montiel C. 2010. Identifying Good Practices and Programme Examples for Prescribed Burning and Suppression Fire. In Best Practices of Fire Use - Prescribed Burning and Suppression Fire Programmes in Selected Case-Study Regions in Europe, Montiel C, Kraus D (eds), European Forest Institute Research Report 24, Joensuu, 35-44.

Gómez-Rey MX, Couto-Vázquez A, García-Marco S, González-Prieto SJ. 2013. Impact of fire and post-fire management techniques on soil chemical properties. Geoderma 195-196: 155-164. DOI: 10.1016/j.geoderma.2012.12.005.

Janzen HH. 2005. Soil carbon: A measure of ecosystem response in a changing world? Canadian Journal of Soil Science 85: 467-480. DOI: 10.4141/S04-081

IUSS Working Group WRB. 2014. World reference base for soil resources 2014. International soil classification system for naming soils and creating legends for soil maps. World Soil Resources Reports No. 106. FAO, Rome. DOI: 10.1017/S0014479706394902.

Jobbágy EG, Jackson RB. 2000. The vertical distribution of soil organic carbon and its relation to climate and vegetation. Ecological Applications 10: 423-436. DOI: 10.2307/2641104. Knicker H. 2007. How does fire affect the nature and stability of soil organic nitrogen and carbon? A review. Biogeochemistry 85: 91-118. DOI: 10.1007/s10533-007-9104-4.

Knicker H. 2010. "Black nitrogen"- an important fraction in determining the recalcitrance of charcoal. Organic Geochemistry 41: 947-950. DOI: 10.1016/j.orggeochem.2010.04.007.

Knicker H, González-Vila FJ, Polvillo O, González JA, Almendros G. 2005. Fire-induced transformation of $\mathrm{C}$ - and $\mathrm{N}$ - forms in different organic soil fractions from a Dystric Cambisol under a Mediterranean pine forest (Pinus pinaster). Soil Biology and Biochemistry 37: 701-718. DOI: 10.1016/j.soilbio.2004.09.008.

Komac B, Alados CL, Bueno CG, Gómez D. 2011a. Spatial patterns of species distributions in grazed subalpine grasslands. Plant Ecology 212: 519-529. DOI: 10.1007/s11258-0109842-6.

Komac B, Alados CL, Camarero JJ. 2011b. Influence of topography on the colonization of subalpine grasslands by Echinospartum horridum. Artic and Alpine Research 43: 601611. DOI: $10.1657 / 1938-4246-43.4 .601$. 
Komac B, Kefi S, Nuche P, Escós J, Alados CL. 2013. Modeling shrub encroachment in subalpine grasslands under different environmental and management scenarios. Journal of Environmental Management 121: 160-169. DOI: 10.1016/j.jenvman.2013.01.038.

Körner C. 2003. Alpine plant life: functional plant ecology of high mountain ecosystems. Alpine plant life functional plant ecology of high mountain ecosystems. DOI: 10.1659/02764741(2001)021[0202:APLFPE]2.0.CO;2.

Larroulet MS, Hepper EN, Redondo MPA, Belmonte V, Urioste AM. 2016. The Caldenal ecosystem: Effects of a prescribed burning on soil chemical properties. Arid Land Research and Management 30: 105-119. DOI: 10.1080/15324982.2015.1046198.

López-Poma R, Bautista S. 2014. Plant regeneration functional groups modulate the response to fire of soil enzyme activities in a Mediterranean shrubland. Soil Biology and Biochemistry 79: 5-13. DOI: 10.1016/j.soilbio.2014.08.016.

Lyet A, Cheylan M, Prodon R, Besnard A. 2009. Prescribed fire and conservation of a threatened mountain grassland specialist: A capture-recapture study on the Orsini's viper in the French alps. Animal Conservation 12: 238-248. DOI: 10.1111/j.14691795.2009.00245.x.

Marinas A, García-González R, Aldezabal A, Palacio S, Gómez-García YD. 2004. Interés ecológico y pastoral del erizón (Echinospartum horridum (Vahl) Rothm. In Pastos y ganadería extensiva, García-Criado B, García-Ciudad A, Vázquez de Aldana BR, Zabalgogeazcoa I (eds.), SEEP-IRNASA, Salamanca, 117-122.

Mataix-Solera J, Cerdà A, Arcenegui V, Jordán A, Zavala LM. 2011. Fire effects on soil aggregation: a review. Earth-Science Reviews 109: 44-60. DOI: 10.1016/j.earscirev.2011.08.002

Montané F, Romanyà J, Rovira P, Casals P. 2010. Aboveground litter quality changes may drive soil organic carbon increase after shrub encroachment into mountain grasslands. Plant and Soil 337: 151-165. DOI: 10.1007/s11104-010-0512-1.

Pietikaeinen J, Fritze H. 1995. Clear-cutting and prescribed burning in coniferous forest: Comparison of effects on soil fungal and total microbial biomass, respiration activity and nitrification. Soil Biology \& Biochemistry 27: 101-109. DOI: 10.1016/00380717(94)00125-K.

This article is protected by copyright. All rights reserved. 
Rutigliano FA, De Marco A, D’Ascoli R, Castaldi S, Gentile A, Virzo De Santo A. 2007. Impact of fire on fungal abundance and microbial efficiency in $\mathrm{C}$ assimilation and mineralisation in

a Mediterranean maquis soil. Biology and Fertility of Soils 44: 377-381. DOI: 10.1007/s00374-007-0214-x.

Saá A, Trasar-Cepeda MC, Carballas T. 1998. Soil P status and phosphomonoesterase activity of recently burnt and unburnt soil following laboratory incubation. Soil Biology \& Biochemistry 30: 419-428. DOI: 10.1016/S0038-0717(97)00120-X.

Saá A, Trasar-Cepeda MC, Gil-Sotres F, Carballas T. 1993. Changes in soil phosphorus and acid phosphatase activity immediately following forest fires. Soil Biology \& Biochemistry 25 : 1223-1230. DOI: 10.1016/0038-0717(93)90218-Z.

San Emeterio L, Múgica L, Ugarte MD, Goicoa T, Canals RM. 2016. Sustainability of traditional pastoral fires in highlands under global change: Effects on soil function and nutrient cycling. Agriculture, Ecosystems \& Environment 235: 155-163. DOI: 10.1016/j.agee.2016.10.009.

Tälle M, Deák B, Poschlod P, Valkó O, Westerberg L, Milberg P. 2016. Grazing vs. mowing: A meta-analysis of biodiversity benefits for grassland management. Agriculture, Ecosystems and Environment 222: 200-212. DOI: 10.1016/j.agee.2016.02.008

Vance ED, Brookes PC, Jenkinson DS. 1987. An extraction method for measuring soil microbial biomass C. Soil Biology \& Biochemistry 19: 703-707. DOI: 10.1016/0038-0717(87)900526.

Williams RJ, Hallgren SW, Wilson GWT. 2012. Frequency of prescribed burning in an upland oak forest determines soil and litter properties and alters the soil microbial community. Forest Ecology and Management 265: 241-247. DOI: 10.1016/j.foreco.2011.10.032. 


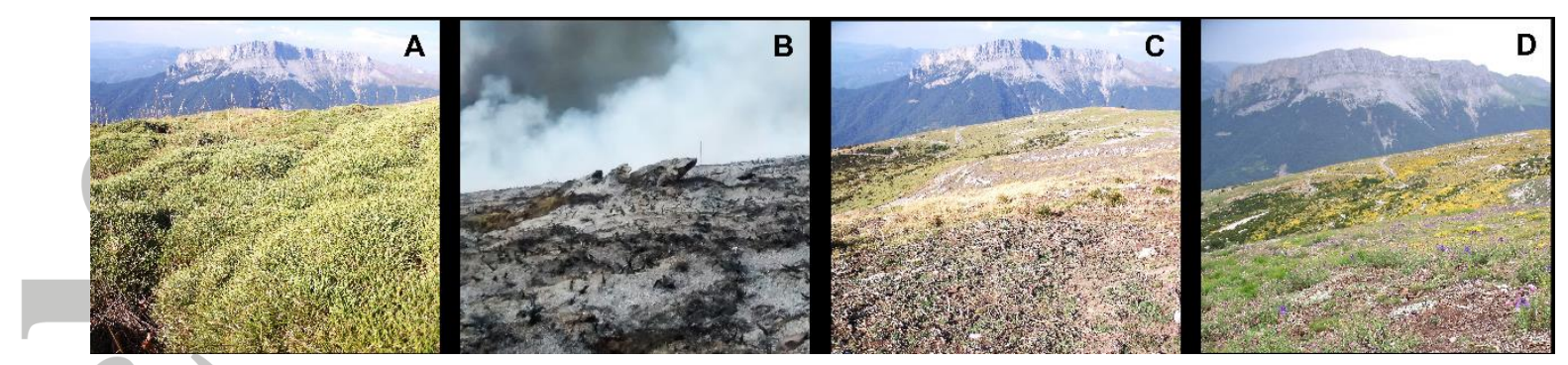

Fig. 1. Views of the study area: (A) experimental plot encroached by Echinospartum horridum before the prescribed burning in 2015, (B) the same plot immediately after burning in 2015 (TO) and (C) one year later (T1) and (D) an experimental plot five years after the prescribed burning in 2011 (T5)
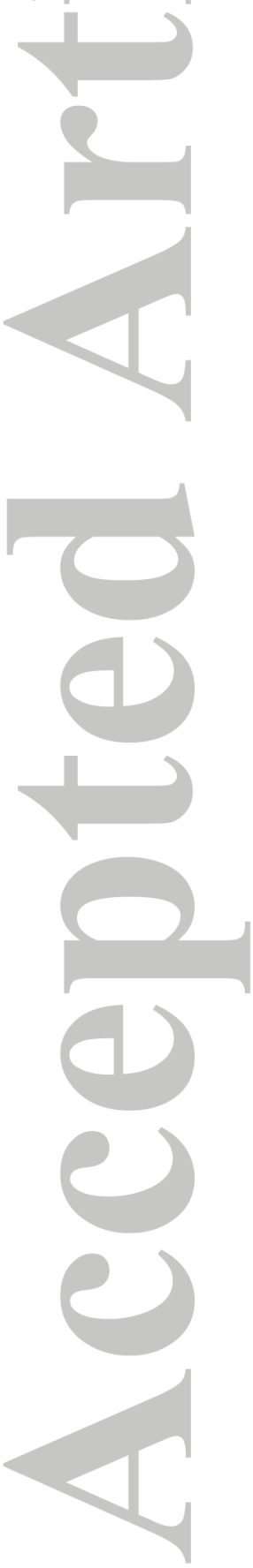


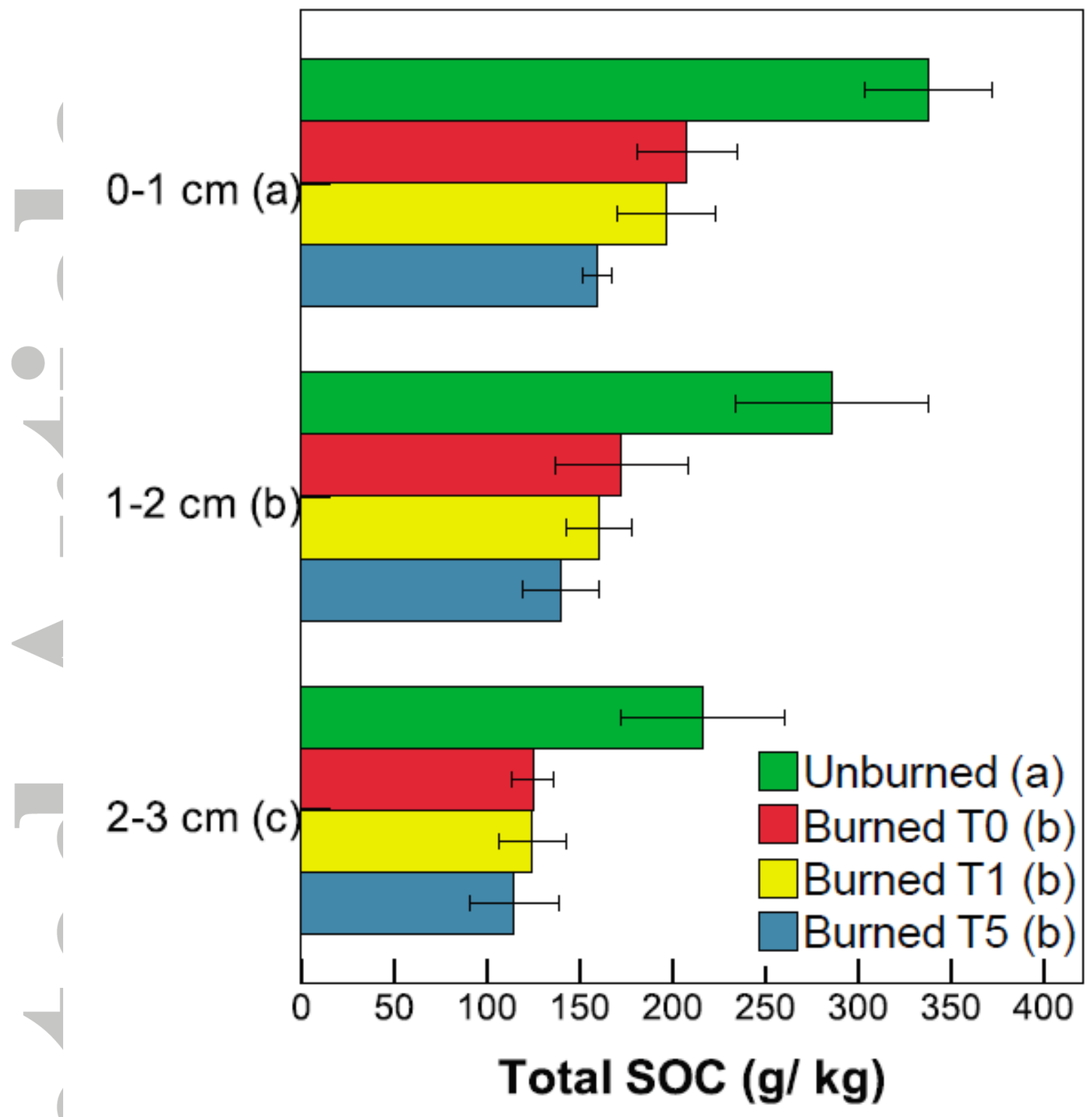

a 


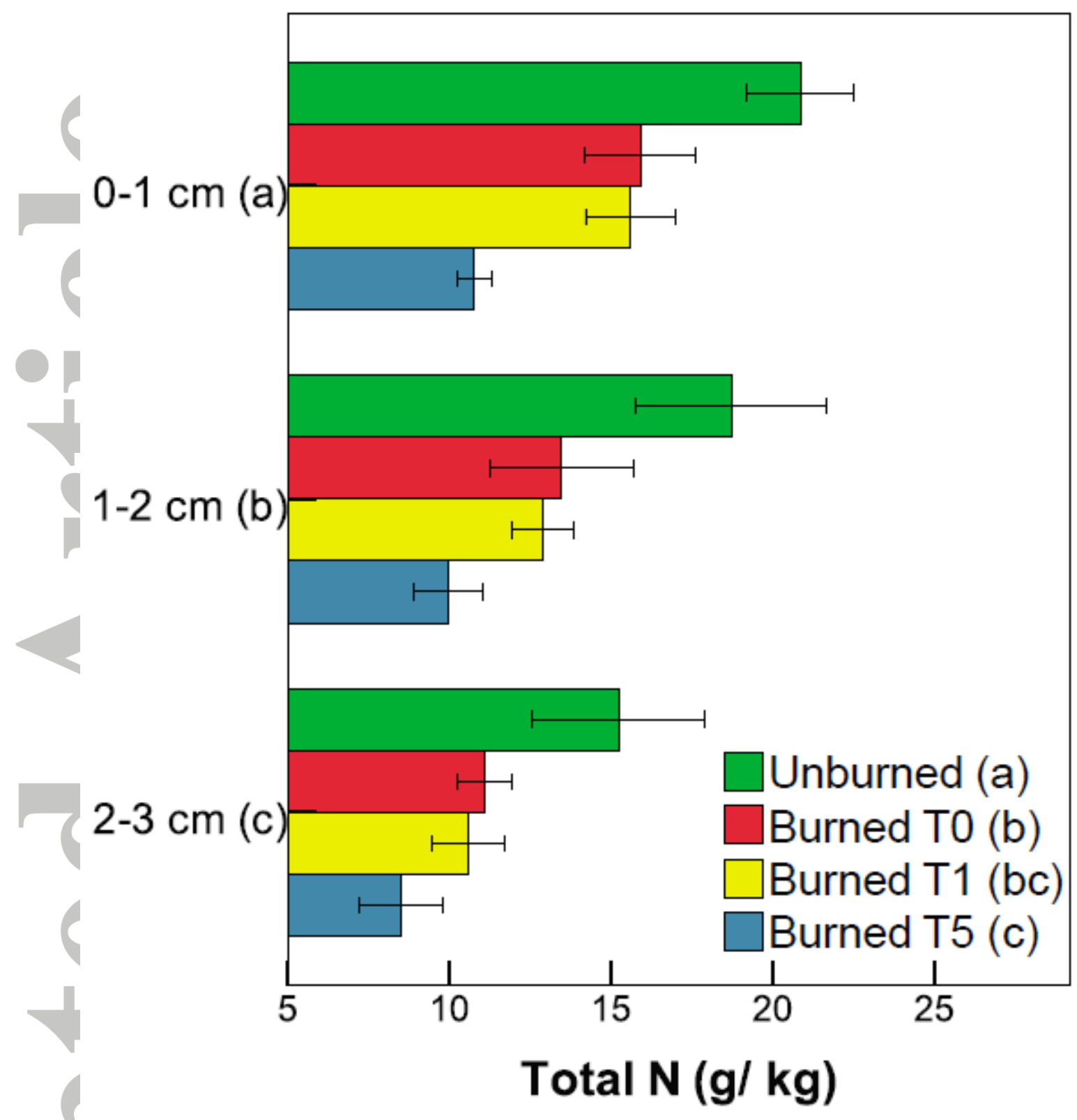

b 


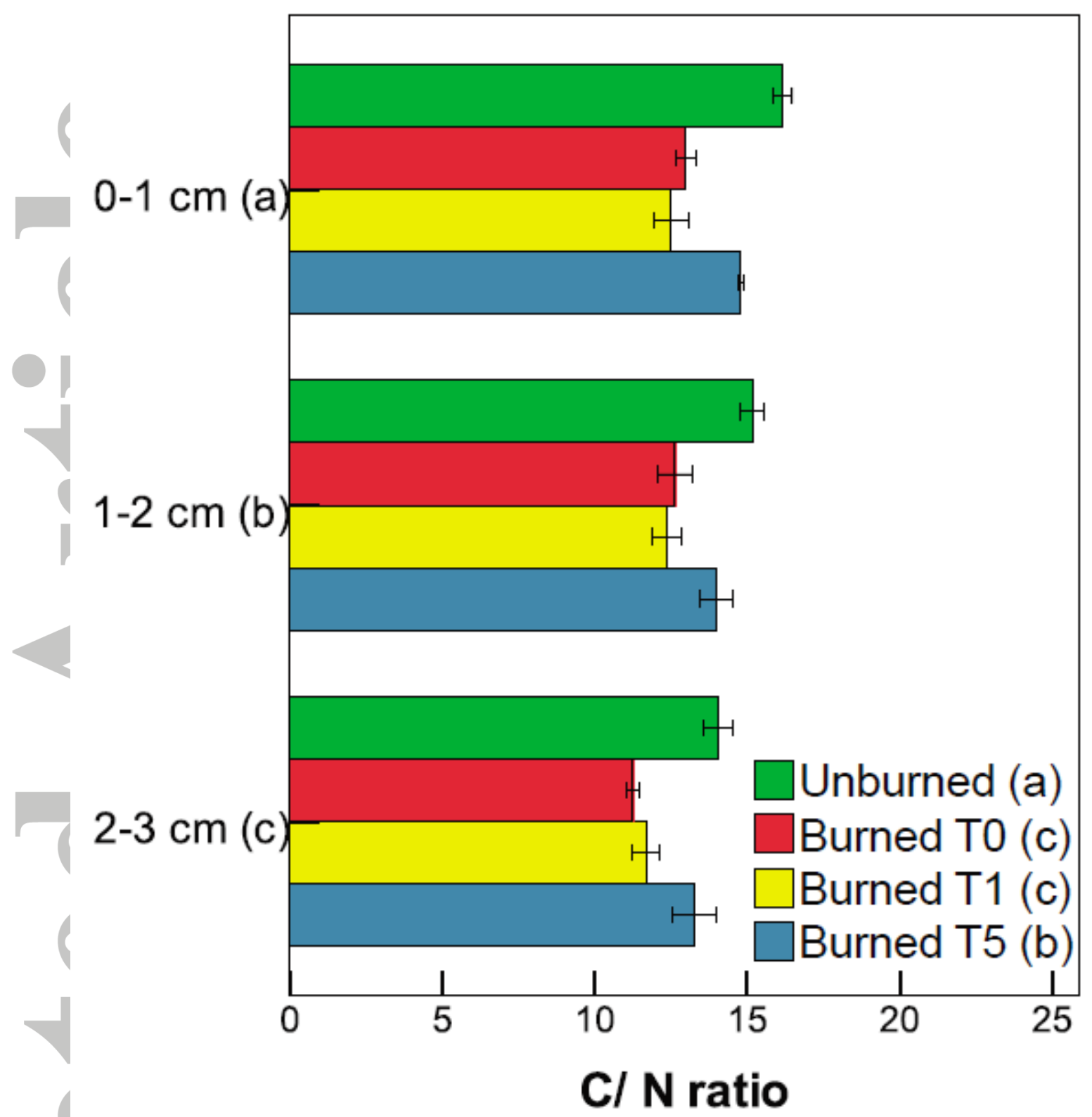

C 


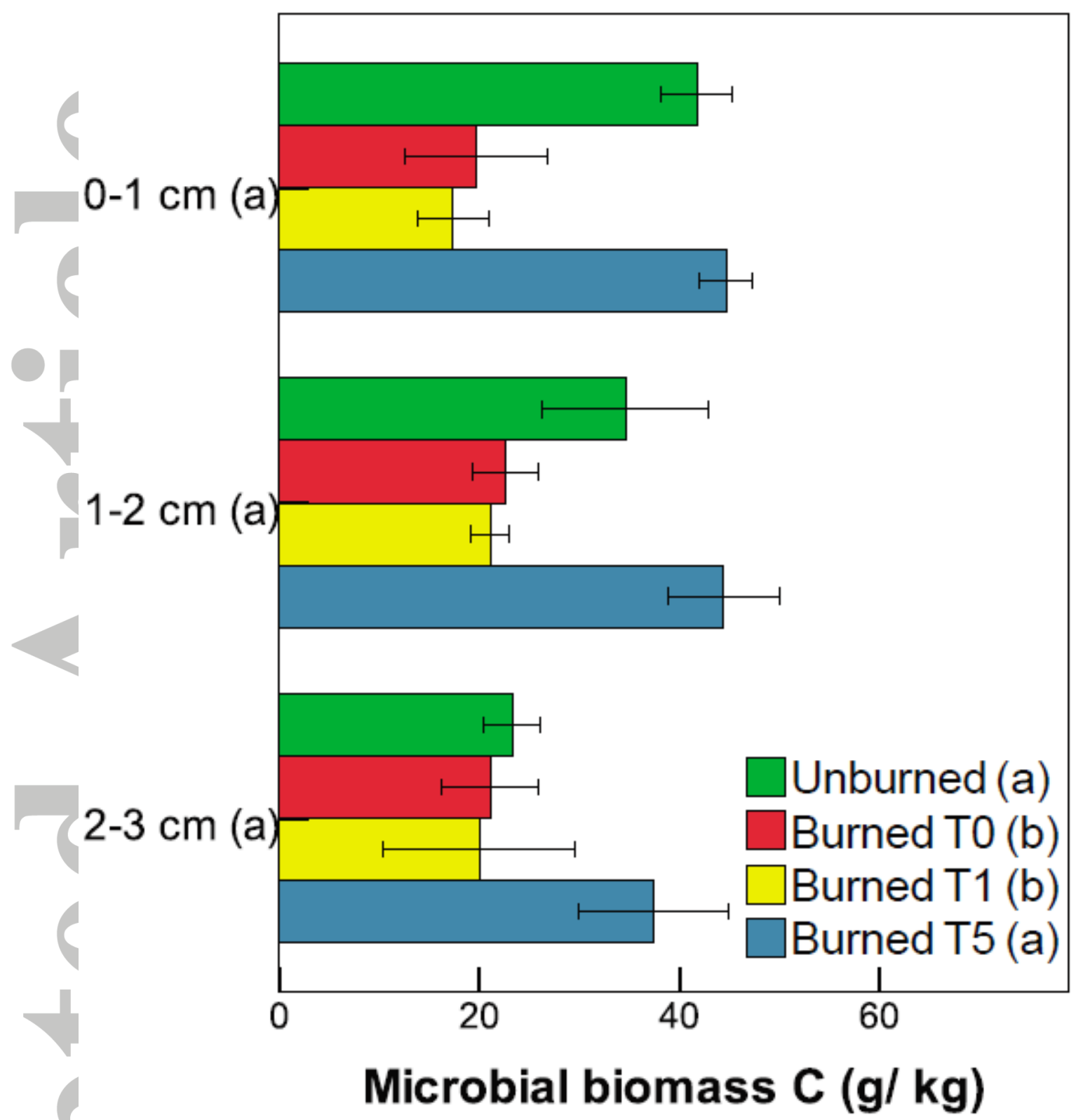

d

Fig. 2. Temporal evolution of soil organic matter-related properties in the first three centimetres of the soil (mean $\pm \mathrm{SEM}, \mathrm{N}=3$ ). (A) SOC, (B) $\mathrm{N},(C) \mathrm{C} / \mathrm{N}$ ratio, (D) microbial biomass $\mathrm{C}$. Significant differences $(P<0.05)$ between the depths and sampling times are represented by different letters in the axes and legend labels. T0, T1 and T5 are 0 , one and five years after burning, respectively. 


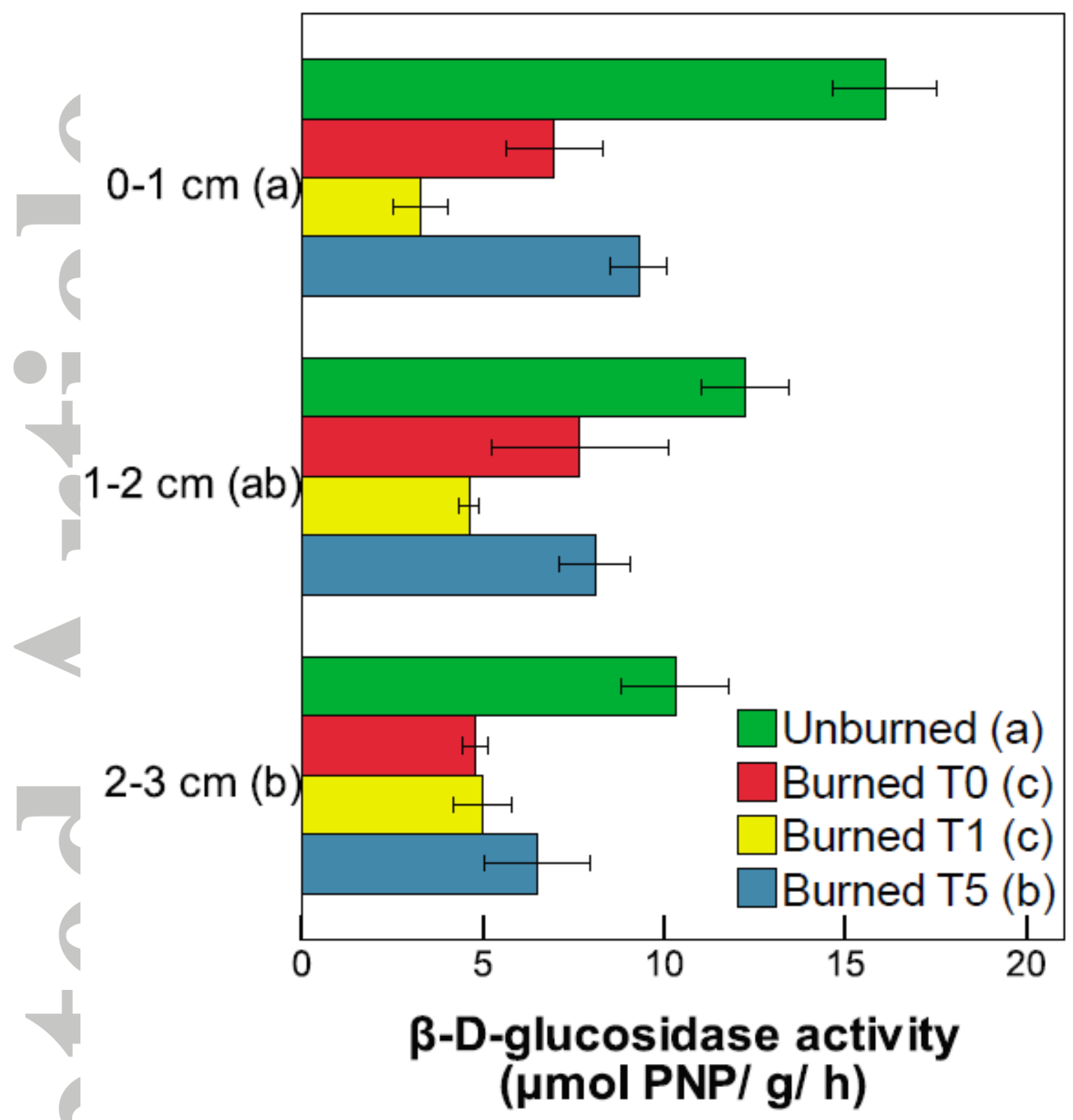

a 


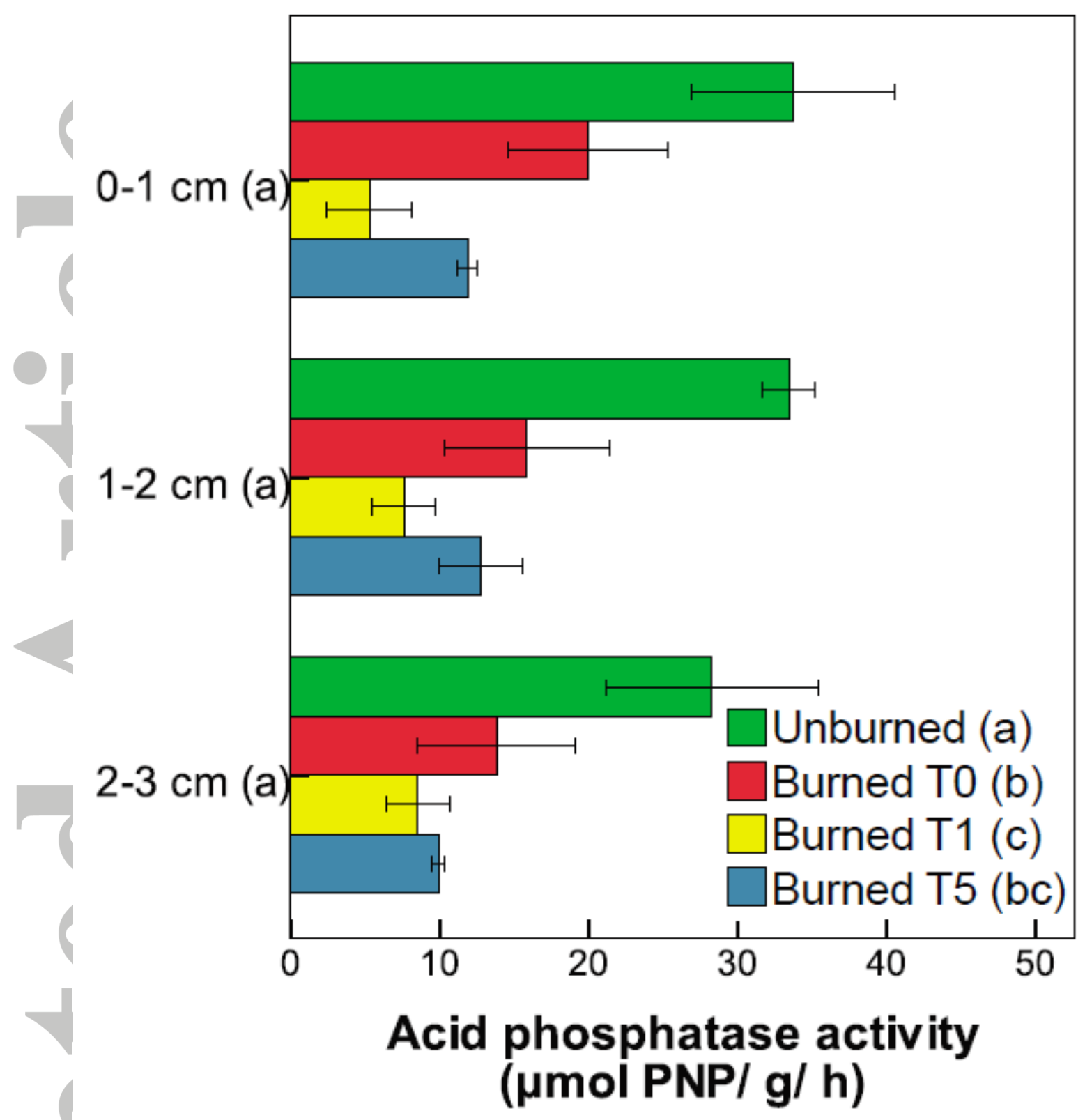

b 


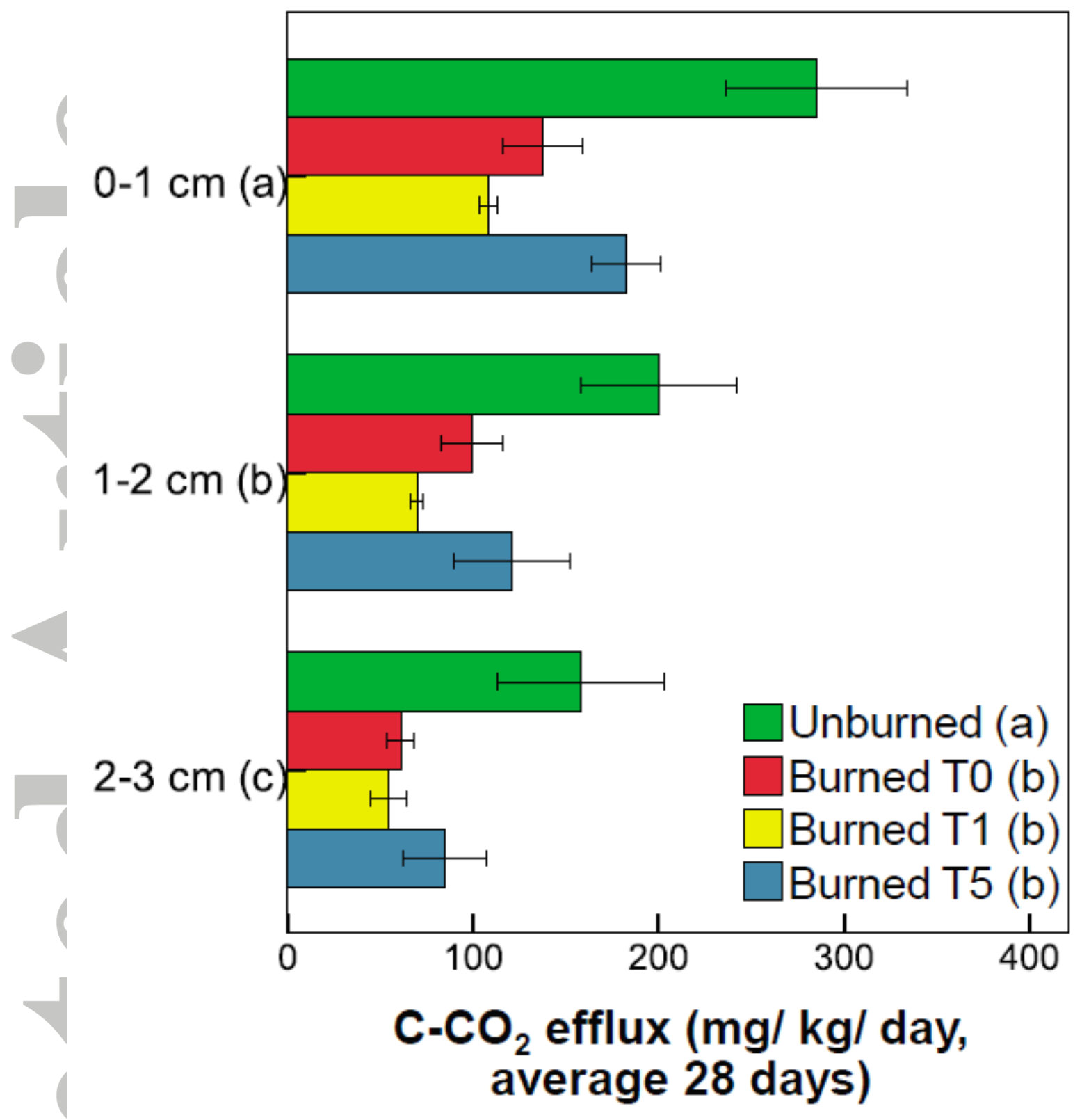

C

Fig. 3. Temporal evolution of soil biological properties in the first three centimetres of the soil (mean $\pm \mathrm{SEM}, \mathrm{N}=3$ ). (A) $\beta$-D-glucosidase activity, (B) acid phosphatase activity, (C) $\mathrm{C}-\mathrm{CO}_{2}$ efflux. Significant differences $(P<0.05)$ between the depths and sampling times are represented by different letters in the $\mathrm{y}$-axis and legend labels. T0, T1 and T5 are 0, one and five years after burning, respectively. 
Table 1. Ground cover (\%) at the experimental areas burned one (T1) and five (T5) years before. Standard deviation in parentheses; $N=6$ (T1), $N=5$ (T5)

\begin{tabular}{lll}
\cline { 2 - 3 } & T1 & T5 \\
\hline Bare soil & $42(4)$ & $5(7)$ \\
Rock and stones & $11(7)$ & 21 \\
& & $(11)$ \\
Burned plant & $24(8)$ & $18(6)$ \\
residues & & \\
Herbaceous plants & $14(9)$ & $43(6)$ \\
Organic debris & $9(3)$ & $13(6)$ \\
\hline
\end{tabular}

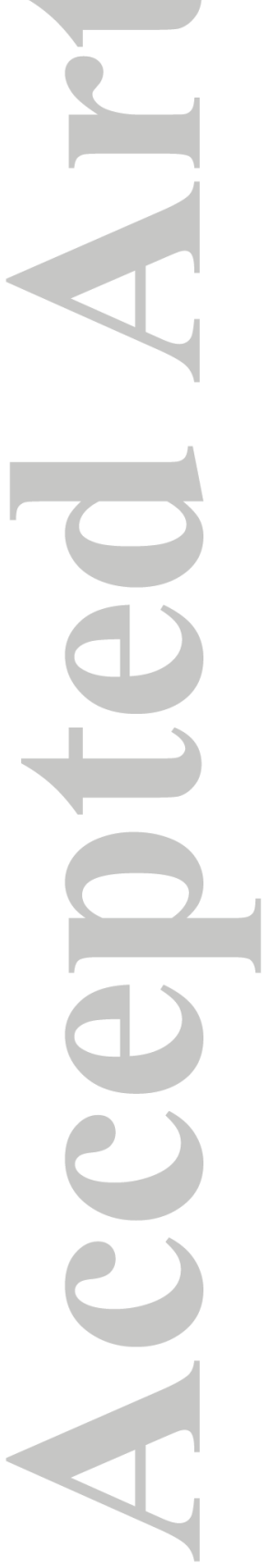


Table 2. Repeated measures ANOVA of the investigated soil properties in relation to the time elapsed since the burn, the soil depth and the interaction Time $\mathrm{x}$ Depth

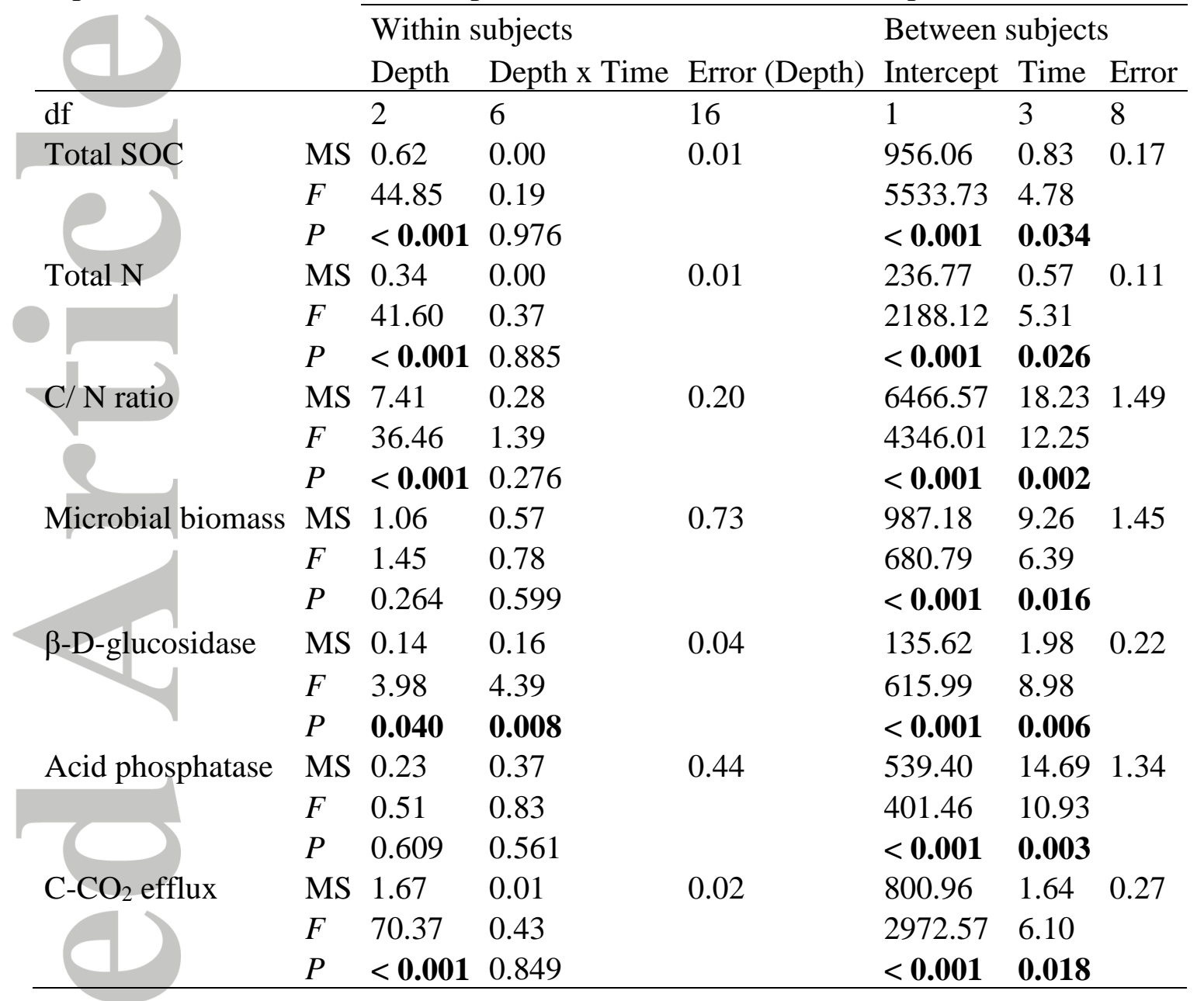

MS: mean square; df: degrees of freedom 
Table 3. Resistance, recovery and resilience after the prescribed burning. T1 and T5 are one and five years after burning, respectively.

\begin{tabular}{|c|c|c|c|c|}
\hline 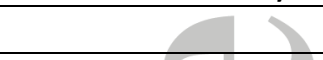 & Resistance (\%) & Recovery T1 (\%) & Recovery T5 (\%) & Resilience (\%) \\
\hline \multicolumn{5}{|c|}{ Total soil organic $\mathrm{C}\left(\mathrm{g} \mathrm{kg}^{-1}\right)$} \\
\hline $0-1 \mathrm{~cm}$ & -38.5 & -41.8 & -52.8 & -14.3 \\
\hline $1-2 \mathrm{~cm}$ & -39.8 & -44.0 & -51.1 & -11.4 \\
\hline $2-3 \mathrm{~cm}$ & -42.2 & -42.4 & -46.9 & -4.7 \\
\hline average & -40.2 & -42.7 & -50.3 & -10.1 \\
\hline \multicolumn{5}{|l|}{ Total soil $\mathrm{N}\left(\mathrm{g} \mathrm{kg}^{-1}\right)$} \\
\hline $0-1 \mathrm{~cm}$ & -23.7 & -25.2 & -48.3 & -24.7 \\
\hline $1-2 \mathrm{~cm}$ & -28.1 & -31.1 & -46.9 & -18.8 \\
\hline $2-3 \mathrm{~cm}$ & -27.3 & -30.6 & -44.1 & -16.9 \\
\hline average & -26.4 & -29.0 & -46.4 & -20.1 \\
\hline \multicolumn{5}{|c|}{ Microbial biomass $\mathrm{C}\left(\mathrm{g} \mathrm{kg}^{-1}\right)$} \\
\hline $0-1 \mathrm{~cm}$ & -52.7 & -58.3 & 7.1 & 59.8 \\
\hline $1-2 \mathrm{~cm}$ & -34.7 & -39.1 & 28.4 & 63.1 \\
\hline $2-3 \mathrm{~cm}$ & -9.6 & -14.2 & 60.5 & 70.0 \\
\hline average & -32.3 & -37.2 & 32.0 & 64.3 \\
\hline \multicolumn{5}{|c|}{$\beta$-D-glucosidase $\left(\mu \mathrm{mol}\right.$ PNF g $\left.{ }^{-1} \mathrm{~h}^{-1}\right)$} \\
\hline $0-1 \mathrm{~cm}>>$ & -56.7 & -79.8 & -46.9 & 9.8 \\
\hline $1-2 \mathrm{~cm}$ & -37.4 & -62.3 & -41.9 & -4.4 \\
\hline $2-3 \mathrm{~cm}$ & -53.6 & -51.5 & -50.0 & 3.7 \\
\hline average & -49.2 & -64.5 & -46.3 & 3.03 \\
\hline \multicolumn{5}{|c|}{ Acid phosphatase $\left(\mu \mathrm{mol}\right.$ PNF g $\left.{ }^{-1} \mathrm{~h}^{-1}\right)$} \\
\hline $0-1 \mathrm{~cm}$ & -40.9 & -84.2 & -64.8 & -23.9 \\
\hline $1-2 \mathrm{~cm}$ & -52.5 & -77.2 & -61.8 & -9.3 \\
\hline $2-3 \mathrm{~cm}$ & -51.2 & -69.7 & -64.9 & -13.7 \\
\hline average & -48.2 & -77.0 & -63.8 & -15.6 \\
\hline \multicolumn{5}{|c|}{$\mathrm{C}-\mathrm{CO}_{2}$ efflux ( $\mathrm{mg} \mathrm{kg}^{-1} \mathrm{dí}^{-1}, 28$ days) } \\
\hline $0-1 \mathrm{~cm}$ & -51.7 & -62.0 & -37.1 & 14.5 \\
\hline $1-2 \mathrm{~cm}$ & -50.4 & -65.2 & -51.9 & -1.5 \\
\hline $2-3 \mathrm{~cm}$ & -61.5 & -65.5 & -59.7 & 1.8 \\
\hline average & -54.5 & -64.2 & -49.6 & 4.93 \\
\hline
\end{tabular}

